\title{
Spanish Literature and the Recovery of Historical Memory
}

\author{
JOSÉ M. GONZÁLEZ \\ Instituto de Filosofía, Centro de Ciencias Humanas y Sociales, Consejo \\ Superior de Investigaciones Científicas, c/ Albasanz, 26-28, 28037 Madrid, \\ Spain. E-mail: jmgonzalez1950@gmail.com
}

This article analyses the recovery of the historical memory of the Spanish Civil War in the last decade, after so many years of silence, forgetfulness and oblivion. Four points are developed: first, how this recovery is achieved by the civil society in general and by the Association for the Recovery of Historical Memory in particular. Secondly, there is a brief allusion to the quarrel between historians and philosophers about the place of memory and remembrance for the construction of the history of Spain. Thirdly, a reference to the recent Historical Memory Law is made, and finally there is a point about the important role played by literature in recovering the memory of many painful facts of the Civil War and Franco's dictatorship from the point of view of the victims.

\section{The Recovery of Historical Memory}

It has often been said that Europe needs what Thomas Mann called 'the spirit of narration'. The stories told by poets, those stories that speak to us of good and evil, frame the horizon of our lives, much more so than do the laws born from a Parliament. The writers, and the spirit of narration flowing from them, are able to illuminate our lives in a special way by keeping alive the memory of the victims of history. And the victims of European history number in the millions. On their lives - cut short by wars, economic or political exile, or other tragedies, or the economic consequences of the diverse forms of European colonization in other continents the well-being of European societies is based. We owe the victims of history a 'duty of memory,' as the philosopher Reyes Mate put it. To narrate means to remember, to bring into the present the memory of those on the losing side of history.

In what follows, I will be concerned with the memory of the victims of the Spanish Civil War, and specifically of those whose blood covered the battlefields, 
who were shut away in the desperation of Spanish concentration camps, or in Southern France or North Africa, of the innumerable soldiers of the republican side, lost to their families cast into a long and painful exile, and of the hundreds of thousands of people that have never been able to return to Spain. The victims of Franco's repression during the Civil War and the years of violent repression that ensued have been silenced for too long. In 2006, we experienced a period of anniversaries. On 14 April, we celebrated the 75th anniversary of the proclamation of the Second Republic in Spain, which led to one of the greatest flowerings of culture and literature in our history. On 18 July, we commemorated that in 1936 a bloodthirsty military coup put an end to the republican dream, leading to three years of cruel civil war, and the long exile of thousands and thousands of people.

Many years have passed since the events of the 1930s, but during the long years of the dictatorship the loser's stories could not be told in more than a whisper. Luis Martín Santos correctly defined this period with the title of his novel Tiempo de Silencio (Time of Silence). The painful memories of the past, and of the losers of the Civil War, were covered with a mantle of silence that prevented people talking about them. Franco's death in 1975 might have offered a suitable opportunity for remembrance. Still, the need to construct a democratic future with the consensus of all political forces (both the heirs of the dictatorship and the new left wing parties that had their old roots in the republican legality and had fought against Franco's regime), ensured that the victims of the Civil War and the long post-war period passed again into the background. Thus, the Spanish political 'Transition' was born under the sign of obscurity and of a 'pact of silence' between the political forces: speaking about the past was avoided in order to enable a consensus of all the political right and left wing parties around the Constitution of 1978. To a great extent, this was a 'time of forgetfulness'. Only since the 1990s does a 'time of memory' seem to have emerged, a time of public remembrance of those traumatic facts for several generations of Spaniards. 'Time of silence', 'time of forgetfulness' and 'time of memory' are the three forms in which we have faced very hard and painful memories.

In recent years, the Association for the Recovery of Historical Memory has taken up the challenge to help the efforts of private citizens in searching and identifying the corpses of many republicans shot during the Civil War or during the subsequent Repression, and buried in common graves without any identification, in roadside ditches, or in unmarked graves in the cemeteries. Grandchildren want to know the tragic circumstances of the death of their grandparents, and to honour their memory. Seventy years have passed: now it is possible to raise these issues without resentment or feelings of revenge. People want to know a history that was denied to them during Franco's regime, a period in which people were indoctrinated by the official version of the winners. The task now is 
to remember those who experienced persecution or death for their ideas and their loyalty to the Spanish Republic, a democratically elected regime.

By popular movement, burial places of the disappeared on the outskirts of small towns and villages in the province of León have begun to be identified. So far, approximately 300 corpses have been identified through DNA tests. For many now-old people, the recognition of the mortal remains of their relatives has been a very hard experience, but they have been able to fulfil a fundamental desire: to recover the remains of their relatives and give them a proper burial in a decent place. In other cases, the massive executions have made the recovery of the bodies impossible, but the names of the executed have been identified for the first time. This is the case with a common grave in Santander, where the research of Antonio Hontañón has been able to give full names to 850 people. It took Hontañón more than 20 years to do this, an effort which he justified as follows: 'It was tremendously unfair. As if they had killed them twice. First, with one bullet, and second, by stealing their identity' (El Pais, 03/02/2007: 24).

In 2006, the City Council of Valencia tried to build over the common graves of those assassinated at the end of the Civil War and during the early years of the Franco regime, when Valencia, the last capital of Republican Spain, fell to Franco's army. Many who were not able to escape in time were eliminated and buried anonymously. However, numerous complaints of left-wing parties and citizen movements led to a court order to stop the work already initiated.

At the end of 2005, the Association for the Recovery of Historical Memory denounced the disappearance of 30,000 people between 1936 and 1948, the years between the beginning of the Civil War and the end of the first part of Franco's dictatorship. The Association tries to recover the memory of the victims and seeks appropriate reparations for their families.

Some newspapers now quite frequently carry obituary notices in memory of persons that were executed or who died in jail or in exile. With a delay of 70 years, the relatives thus vindicate the memory of somebody involved in the cause of the Republic and in the defence of public rights. Right-wing newspapers have responded with the publication of obituary notices for those shot by the republicans. This is now popularly known as 'the obituary notices war'. The situation, however, is asymmetrical: whereas the authorities of the Franco regime recovered the corpses and the memory of those shot by the Republic, for the immense majority of those assassinated by the Franco regime it has been impossible to recover their names and to vindicate their memory.

The Association for the Recovery of Historical Memory has played an important role in the recent public discussion about the necessity of recovering not only the corpses of the victims of the violence, but also their names to save them from forgetfulness. Furthermore, the Association has had an impact on the present situation in which, according to the surveys, almost $70 \%$ of the Spanish 
population agree with the investigation of the Civil War and the rehabilitation of the victims. The Spanish Parliament declared 2006 the Year of Historical Memory, and the government presented a bill to recognise and extend the rights and establish measures in favour of those who suffered persecution or violence during the Civil War and Franco's dictatorship.

\section{History or memory? The quarrel between historians and philosophers}

Historians have also been occupied by the problem, but they are divided over the force of memory and remembrance. Perhaps Santos Juliá is the best representative of those historians that advocate a purely scientific study of history and argue the impossibility of recovering collective memory. He begins a recent article, ironically entitled 'Under the empire of memory', with these words:

In the last years we live, not only in Spain, under the sign of memory. About thirty years ago, we were interested to know what had happened during the Republic and the Civil War: establishing the facts, interpreting texts, analysing the situations. Today, when a new generation of historians, writers, and cultural critics who were born around the Transition has come to occupy the first row, it is no longer what happened what is interesting but its memory; not the real facts but its representations, that acquire a kind of independent existence, independent from the represented facts. (Ref. 1, p. 7)

Santos Juliá ${ }^{1}$ identifies himself with the first generation of historians that explicitly rejected the collective memory imposed by Franco's regime and the Catholic Church, against the myth of the Civil War as a religious crusade. For him, the task is to study the causes of the Civil War under the motto 'not to remember, but to know'. Instead, for the present generation of historians, born in the 1960s and 1970s, it is very important to recover the memory and to do justice to the victims, saving them from forgetfulness and obscurity. The motto now is 'to remember in order to know'. Bare knowledge of the facts is no longer sufficient: it becomes necessary to promote the memory of the victims of injustice.

For Santos Juliá, it is impossible to recover historical memory because there cannot be only one memory: many memories exist, and they exist in permanent conflict. Additionally, it is impossible to do justice to the Civil War because it was a war of extermination on both sides: civil wars can only end with a general amnesty, when people forget the past and sit down to negotiate a future.

From a different position, the philosopher Reyes $\mathrm{Mate}^{2}$ has insisted on the importance of memory as the capacity to read what was never written in the book of life. Memory contributes with a different point of view to the knowledge of the past, because it is related to the past of the defeated. Starting from Walter Benjamin's ideas, Reyes Mate states that memory and justice are synonyms, as 
are forgetfulness and injustice. And he reminds us of the imperative of memory formulated by Theodor W. Adorno, 'Aller politischer Unterricht endlich sollte zentriert sein darin, dass Auschwitz nicht sich wiederhole,' and which Reyes Mate translates as: 'You must remember so that the barbarism of Auschwitz shall not be repeated'.

Memory must reorient our thoughts and our actions so that Auschwitz is not repeated. As opposed to the necessity of forgetting in order to live, as formulated by Nietzsche, Reyes Mate advocates thinking about ethics and politics in a different way, and to consider the issues of rights and justice from the vantage point of the victims' memory (Ref. 2, pp. 120-128).

The current situation is that people want to know. They want to know where the bodies of their disappeared are, why they were shot, and in what common graves their mortal remains lie. They want to know the names of the 850 buried in Cantabria and the 7250 shot in the cemetery of Valencia. They want to honour the memory of their dead, recover their forgotten dignity, close their own wounds and carry on with their lives. Opposed to the strategy of forgetfulness and silence about the past that was at the basis of the reconciliation between Spaniards at the end of Franco's regime, today a new strategy is made possible, rooted in the knowledge of the pain of the Civil War victims and the repression of Franco's dictatorship.

\section{The Historical Memory Law}

In the Summer of 2006, the Zapatero socialist government introduced a 'Bill in order to recognize and extend the rights, and to establish measures in favour, of those that suffered persecution or violence during the Civil War and the dictatorship' to Parliament. The general public knows the resulting law as the 'Historical Memory Law'. This law intends to remember the spirit of reconciliation and concord that made possible the political Transition from dictatorship to democracy and that allowed the Constitution of 1978 to be written, the best model of coexistence in the whole of Spanish history. Although over the last few years Parliament has adopted some measures to appease those that suffered the consequences of the Civil War and Franco's dictatorship, there is still much left to do. It is important that the present generations honour and recover all those that suffered injustice and offence in those painful moments of our past: those who were killed, those who were imprisoned for years, those who were condemned to hard labour or had to live in concentration camps, and those who had to leave Spain in a long and painful exile. The bill in question establishes an individual right to the personal and familiar memory of each citizen and generally rejects as unjust all sentences pronounced and sanctions imposed upon, and violence perpetrated against, persons, during the Civil War and the dictatorship it gave rise to, and in whatever field, for political or ideological reasons. 
In addition, there is the possibility of obtaining a personal declaration of rehabilitation and reparation, as a right of all those affected, and that can be exerted by them or their families. In addition, the bill establishes a series of measures:

(1) Improving the economic rights of the families of the victims and granting the families of those that were killed in defence of democracy the right to economic indemnification.

(2) Making possible the location and identification of the disappeared as a final demonstration of respect towards them.

(3) Eliminating the symbols and monuments of the Civil War and the dictatorship because public symbols must be related to encounters, not confrontations.

(4) Special recognition towards the volunteers of the International Brigades and the citizen Associations that distinguished themselves in defending the dignity of the victims.

(5) Bettering an understanding of the past because the duty of memory is based on the knowledge of the tragic facts of the past. Therefore, 'knowing in order to remember' seems to be the best motto. For this goal, the following actions are undertaken:

- A Documentary Centre of Historical Memory is created.

- The role of the present General Archive of the Spanish Civil War with a seat in Salamanca is reinforced.

- The recollection of oral testimonies of the victims of the violence in the Civil War and the repression following upon it is facilitated.

- The State will acquire and protect documents on the Civil War and the dictatorship.

The law tries to heal the wounds still open between the Spaniards, deepening the spirit of concord and reunion that made the political Transition possible. It wants to do this with the conviction that it is not the task of public institutions to establish a certain 'historical memory' or to construct a so-called 'collective memory'; however, the law must protect the right of each individual to a personal and familiar memory as an expression of democratic citizenship.

After a very difficult discussion in the Spanish Parliament, the bill was finally adopted in December 2007.

\section{Literature and memory}

In the last few years, literature has played an eminent role in recovering the memory of many painful facts of the Civil War and the dictatorship from the victims' point of view. Certainly, several decades ago the concentration camps in 
Spain at the beginning of the Franco era were already commemorated in Max Aub's Campo de los Almendros (Almonds camp). In this camp, close to Alicante, 30,000 republicans that had not been able to escape by ship were imprisoned. Jorge Semprún wrote about the Spaniards in German concentration camps during the Second World War. The memory of exile has been kept alive by Francisco Ayala in several novels and in his autobiography, Recuerdos y olvidos (Memory and Oblivion).

Nowadays there is a new movement of young writers who are trying to recover the lost memory of the victims of our history. Manuel Rivas, in his Los libros no arden bien (Books don't burn well) reflects upon Franco's repression in Galicia (Northwest Spain). Dulce Chacón in La voz dormida (The Sleeping Voice) relates the tragedies of republican women imprisoned in Madrid just after the Civil War. Alberto Méndez told stories about the defeated in Los girasoles ciegos (Blind Sunflowers). And Isaac Rosa in El vano ayer (Vain Yesterday) clamours for a new way of remembering the victims of the dictatorship. These are only four examples. But probably the most important one of all has been Javier Cercas's novel Soldados de Salamina (Soldiers of Salamis) which has become a well-known bestseller with more than 50 editions since 2001, and has also become very popular with the film adaptation of David Trueba and the Barcelona stage adaptation.

In Cercas's novel, a young journalist by chance stumbles upon a fascinating and very significant story dating from the Spanish Civil War, and sets out to reconstruct it. When the defeated Republican troops leave for the French border, on their way to exile, and in the midst of the disorder of the exodus, someone takes the decision to execute a group of pro-Franco prisoners. Rafael Sánchez Mazas, founder and ideologist of the Falangist movement and perhaps directly responsible for the fratricidal conflict, is among them. But Sánchez Mazas manages to escape from the collective execution. Hidden in the forest, he is discovered by an anonymous Republican soldier. The soldier points his rifle at him, looks him in the eye and then suddenly calls back to his commander: 'There is no one here!' Sánchez Mazas lived, rose to be a Minister in the Spain of Franco, and even became a relatively well-known writer. The name of the soldier who decided not to shoot him, however, remains unknown.

The novel consists of a triple search. First there is the investigation into the life and survival of Sánchez Mazas, co-founder of the Falange with José Antonio Primo de Rivera, as well as into his political activities and literary achievements, in order to try to understand the man's complex personality. Then there is the search for the anonymous republican soldier who ultimately is the novel's real hero (in fact an anti-hero), and who is finally located in an old people's home in Southern France. But is he really the soldier, the unknown soldier who acted, as Alberto Manguel put it (Ref. 3, p. 3), 'perhaps for no other reason than for the 
goodness of the act itself, beyond any considerations of cause, power, justice or revenge, merely out of the essential kernel of our common humanity?'. Finally, there is the search of the narrator for his own identity as a writer, but also as a person, confronting himself with the terrible past of his own society. In this sense, he is a symbol of the present situation in Spain. For the first time, many Spaniards are confronting their ghosts, their fears about the past and what has been forgotten or kept in the dark for decades. The evolution of the narrator during the process of researching the material was very important for Cercas in order to write Soldiers of Salamis. In a conversation with David Trueba, the director and screenwriter of the film, Javier Cercas said:

The protagonist of the novel undergoes a very clear evolution. It's a process that leads him to change his point of view on many, many things, including his view on the war. At the beginning Cercas thinks, like most people of our generation, that the Civil War is something that belongs to the past, something as remote and distant as, say, the battle of Salamis, something that no longer affects us. And that's why he's so surprised to find out that some of the protagonists of Sanchez Mazas's adventures are still alive: Daniel Angelats, Joaquín Figueras and María Ferré, three of the 'forest friends' (those who helped Sánchez Mazas to survive in the forest till the arrival of Franco's troops). But at the end of the novel he (the narrator) comes to discover that the Civil War is the present, the beginning of the present, something that affects him directly and is alive, something - whether we want to admit it or not - that has influenced the lives of almost everyone in this country [Spain], including his own. (Ref. 4, p. 25)

The Civil War was not a conflict internal only to Spanish society. It was also a European conflict in which many countries were involved. Furthermore, it was the first step to the Second World War. The European Union was created with the essential goal of avoiding conflicts and new wars on our continent. In order to create a new European identity we have to think not only in the future, but also in the past, to try and recover the memory of the victims of our tragic history. Social and personal wounds do not heal by keeping the silence imposed by the winners but, on the contrary, by offering the victims the possibility to speak and to express themselves. And in this awakening of the silenced voice of the victims of violence, literature - European literature - must play an essential role.

\section{Acknowledgement}

This article was in the first instance edited by Dr Iannis Goerlandt.

\section{References}

1. S. Juliá (2006) Bajo el imperio de la memoria. Revista de Occidente, July-August, pp. 302-303.

2. R. Mate (2006) Medianoche en la historia. Comentario a las tesis de Walter Benjamin 'Sobre el concepto de la historia (Madrid: Trotta). 
3. R. Manguel (2002) In Praise of the Enemy. Geist, No. 47.

4. J. Cercas and D. Trueba (2003) Diálogos de Salamina: un paseo por el cine y la literatura (Tusquets, Barcelona). (Extracts of the book translated by A. McLean. In Words Without Borders. The Online Magazine for International Literature: www.wordswithoutborders.org/article. php?lab=Cercas).

\section{About the Author}

José M. González García is Research Professor (Profesor de Investigación) at the Spanish Council for Scientific Research (Consejo Superior de Investigaciones Científicas). From 1998 to 2006 he served as Director of the Research Council's Institute of Philosophy. Earlier, he was Professor in the Faculties of Political Sciences and Sociology and of Philosophy of the Complutense University of Madrid. He has been Visiting Professor at 14 European and Latin American universities. He works in sociological theory and political philosophy, with a main interest in Max Weber. He has directed interdisciplinary research projects about the relationships between Philosophy, Literature and the Social Sciences. He is the author of more than 120 publications; principal monographs include: La máquina burocrática. Afinidades electivas entre Max Weber y Kafka (1989), Las huellas de Fausto. La herencia de Goethe en la sociología de Max Weber (1992), La sociología del conocimiento y de la ciencia (con Emilio Lamo de Espinosa y Cristóbal Torres, 1994), Metáforas del poder (1998) and La diosa Fortuna. Metamorfosis de una metáfora politica (2006). This last book received the Spanish National Prize for non-fiction Literature (Premio Nacional de Ensayo) in 2007. 